\title{
Polycyclic Aromatic Hydrocarbons in the Bottom Sediments of the River - Sea Mixing Zone on the Example of the River Chernaya and the Sevastopol Bay (the Black Sea)
}

\author{
O. V. Soloveva ${ }^{1}$, E. A. Tikhonova ${ }^{1,}{ }^{凶}$, O. A. Mironov ${ }^{1}$, \\ T. O. Barabashin ${ }^{2}$ \\ ${ }^{1}$ A. O. Kovalevsky Institute of Biology of the Southern Seas of RAS, \\ Sevastopol, Russian Federation \\ ${ }^{2}$ Azov-Black Sea branch of "VNIRO" ("AzNIIRKH"), Rostov-on-Don, Russian Federation \\ 凶tihonoval@mail.ru
}

Purpose. The study is aimed at determining concentrations of the polycyclic aromatic hydrocarbons (PAHs) and at revealing their pattern distribution in the bottom sediments of the "river - sea" contact zone on the example of the Sevastopol Bay and the river Chernaya.

Methods and Results. Granulometric composition of the bottom sediments was determined by the decantation and dispersion method. Identification and quantitative determination of PAHs were carried out by the high performance liquid chromatography method. The total PAHs content in the bottom sediments of the area under study varied from 12 to $670 \mathrm{ng} / \mathrm{g}$ of dry weight. The pollutant content was minimum in the river site beyond the geochemical barrier. In the area where the river Chernaya flows into the Sevastopol Bay, the PAHs content was $121 \mathrm{ng} / \mathrm{g}$. The highest PAHs content was revealed in the Sevastopol Bay bottom sediments, more precisely, in $1.5 \mathrm{~km}$ southwest of the river Chernaya flowing into the bay. 14 PAHs were identified in the estuary zone of the river, 4 of them (naphthalene, 2-methylnaphthalene, fluorene, anthracene) were in the trace amounts. The maximum concentration (99\%) of silty material was observed in the Sevastopol Bay water area. The silt fractions were distributed as follows: $20 \%$ - aleuritic-pelite fraction, $79 \%$ - pelitic-aleurite fraction. Directly in the area of the river inflow into the bay, accumulation of the sand fraction (7\%) and the maximum portion of pelitic silts were noted.

Conclusions. The recorded values of PAHs corresponded to the natural non-toxic levels. PAHs identified in the bottom sediments of the river estuary zone are of the mixed, predominantly petrogenic origin. The obtained data show that in the conditions of the "river - sea" contact zone, the PAHs accumulation in general and their individual fractions were governed mainly by presence of silt in the bottom sediments.

Keywords: marginal filter, bottom sediments, particle size distribution, polycyclic aromatic hydrocarbons, Sevastopol Bay, river Chernaya

Acknowledgments: the authors appreciate deeply the staff of the Laboratory of analytical control of water ecosystems ("AzNIIRKH"): the chief specialist Anokhina N. S., the leading researcher, PhD (chemistry) Skrypnik G. V. for determining polycyclic aromatic hydrocarbons in the studied bottom sediments within the framework of the cooperation agreement between the IBSS, RAS and "AzNIIRKH" (cooperation agreement №116 of 15.12.2017); the junior researcher of the Department of Marine Biogeochemistry, MHI RAS, Gurov K. I. for determining the bottom sediments granulometric composition. The work was carried out within the framework of state task № 121031500515-8 "Molismological and biogeochemical foundations of marine ecosystems homeostasis".

For citation: Soloveva, O.V., Tikhonova, E.A., Mironov, O.A. and Barabashin, T.O., 2021. Polycyclic Aromatic Hydrocarbons in the Bottom Sediments of the River - Sea Mixing Zone on the Example of the River Chernaya and the Sevastopol Bay (the Black Sea). Physical Oceanography, [e-journal] 28(3), pp. 338-347. doi:10.22449/1573-160X-2021-3-338-347

DOI: 10.22449/1573-160X-2021-3-338-347

(C) O. V. Soloveva, E. A. Tikhonova, O. A. Mironov, T. O. Barabashin, 2021

(C) Physical Oceanography, 2021 


\section{Introduction}

Marginal filters appear in the mixing zones of river and sea waters at river mouths [1]. Here, significant in scale processes of flocculation and coagulation of dissolved and suspended matters take place. The work of the sedimentation and sorption filter parts is complemented by bioassimilation and biofiltration. All these processes lead to the fact that, on average, 93-95\% of suspended and $20-40 \%$ of dissolved matters of river runoff (including pollution) are deposited in the marginal zone of the world's rivers. In particular, the average annual contribution of river runoff to the bay inorganic carbon budget is 2250-2300 tons per year [2]. As a result, the accumulation of matter, including pollutants of various genesis, often occurs at the places where the river waters flow into the sea. Many of them enter river waters from the entire catchment area of the rivers. These processes negatively affect the ecological state of water areas in the places where river and sea waters mix. It is these zones that have traditionally been inhabited by humans and subjected to anthropogenic pressure. On the other hand, their ecological wellbeing is an important element in preserving the quality of the human environment. Therefore, the study of the processes of transfer, accumulation and transformation of individual classes of pollutants in the river-sea contact zone remains important for solving fundamental and practical problems.

An informative indicator of the degree and nature of anthropogenic impact in natural environments is the content and composition of polycyclic aromatic hydrocarbons (PAHs) [3]. The relevance of the PAHs study is enhanced by the fact that many individual PAHs are priority pollutants with a carcinogenic effect. Their sources in the environment are high-temperature impact on organic matter during anthropogenic activities, as well as natural lithogenic and biogeochemical hydrocarbon fluxes [3].

PAHs enter the urban environment mainly when the fuel is burned by boiler houses, thermal power plants and vehicles [4, 5]. Emissions from carburetor and diesel engines may contain, according to various estimates, $16-2300 \mathrm{mg} / \mathrm{kg}$ of PAHs in the solid fraction of emissions [6]. Almost all compounds getting with the traffic emissions are deposited within $50 \mathrm{~m}$ strip from the transport artery. When washed away from the territory, a significant part of these substances accumulate in the coastal bottom sediments [7], especially in the urban conditions, where the road surface contributes to their washing away from the territory [8].

In recent years, an increase in the number of vehicles in Sevastopol took place. In the region of the water area of the Chernaya River - the Sevastopol Bay biogeochemical barrier a road bridge of the intercity Sevastopol - Simferopol highway is situated, traffic along which increases the intensity of PAHs entering this zone.

Despite the presence of a significant number of PAHs potential sources, the study and control of the content of this class of substances in the Chernaya River area was not carried out. The scientific literature contains fragmentary data on the PAHs content in certain areas of the Sevastopol Bay [9]. In connection with the abovementioned facts, the purpose of this work is to determine the concentrations and identify the distribution patterns of PAHs in the bottom sediments of the river - sea zone (for example, the Chernaya River and the Sevastopol Bay). 


\section{Materials and methods}

Bottom sediment samples taken in the spring of 2019 were used as material for research (Fig. 1). The length of the Chernaya River - the Sevastopol Bay marginal filter lies within 1.27-4.1 km [2]. Sampling stations were selected in accordance with the location and length of the marginal filter zone (Fig. 1): st. 1 - immediately before the beginning of the biogeochemical barrier boundaries in the bay itself within the saline zone; st. 2 - in the water area of the marginal filter, in the brackish-water part, where sedimentation processes are most clearly manifested; st. 3 - in the freshwater river zone. In the bay water area the depths did not exceed $4 \mathrm{~m}$, in the river one $-1 \mathrm{~m}$.

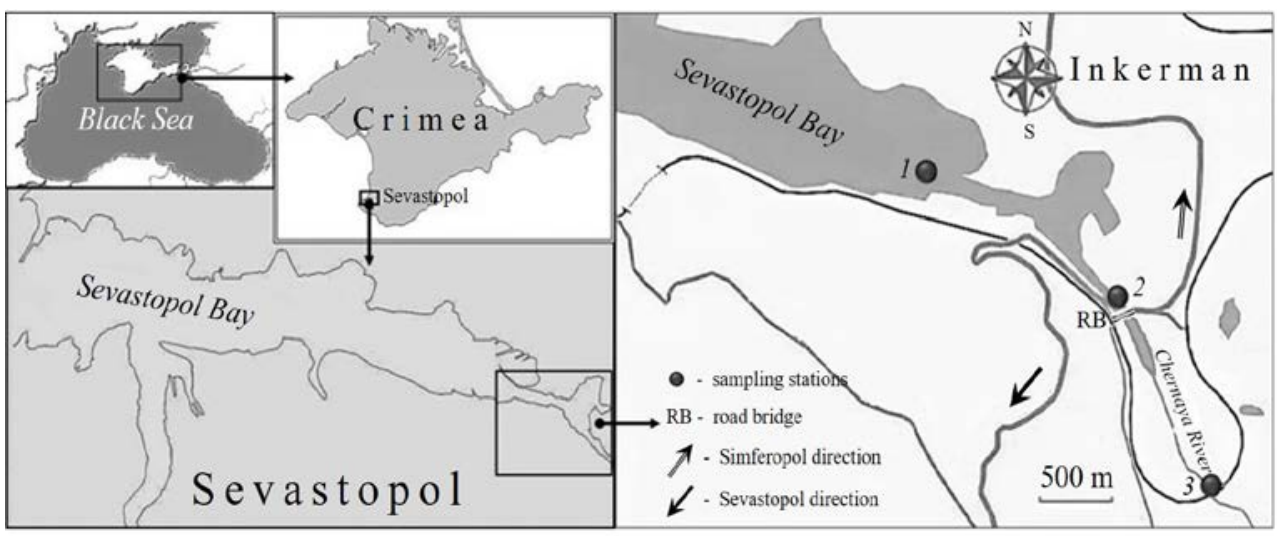

F i g. 1. Scheme of the sea bottom sediments sampling (st. 1 - 3) in the water area under study, 2019

The taking and preparation of bottom sediment samples were carried out in accordance with regulatory documents (GOST 17.1.5.01-80; ISO 5667-12:1995; ISO 5667-19:2001). The granulometric distribution was determined by the method of decantation and dry sieving using standard sieves in accordance with GOST 12536-2014 (introduced from 01.07.2015).

Determination of PAHs in the bottom sediments was carried out in accordance with Federal Guide 1.31.2007.03548 "Methodology for measuring the mass fraction of polycyclic aromatic hydrocarbons in the soil samples and bottom sediments of fresh and marine water bodies." This technique is based on the separation of PAHs from bottom sediments and soils by extraction with a mixture of hexane and acetonitrile (10:1), concentration of the extract, and chromatographic separation of the hydrocarbon fraction in a thin layer of aluminum oxide. The identification and determination of individual PAHs in the bottom sediments was carried out on an EKOM Beta-10US liquid chromatograph with a luminescent detector (RF-5301 PC) and a Yanapak ODS-T column. 


\section{Results and discussion}

Total PAHs content in the bottom sediments of the area under study varied within 12-670 ng/g range of dry residue. Their minimum content was noted in the river part of the study area (st. 3), behind the so-called geochemical barrier. In the area of the Chernaya River inflow to the Sevastopol Bay, near the automobile bridge (st. 2), the total PAHs content ( $\mathrm{PAHs}$ ) was an order of magnitude higher $(121 \mathrm{ng} / \mathrm{g})$ than in the river bottom sediments. The recorded values correspond to the background non-toxic levels [9]. The highest $\sum$ PAHs was recorded in the marine soils of the Sevastopol Bay (st. 1). Thus, it is unlikely that the river runoff in the area under study is the main source of PAHs input. This class of substances probably initially enters the water area of the bay (st. 2). The obtained data are comparable with $\sum$ PAHs in the bottom sediments of the river - sea contact zones of other parts of the Russian coast. Thus, PAHs concentrations in the bottom sediments of various water areas were: in the Gulf of $\mathrm{Ob}$ - the Kara Sea section 11-94 ng/g, in the marginal filters of the Yenisei $11-36 \mathrm{ng} / \mathrm{g}$, the Don - $33 \mathrm{ng} / \mathrm{g}[10,11]$. In the marine soils of the northeastern part of the Black Sea, according to [12], the concentrations of the sum of identified PAHs were within $2-123 \mu \mathrm{g} / \mathrm{kg}$ range of dry residue.

It is known that the Black Sea coast in general and the Sevastopol Bay in particular are prone to oil pollution [13]. Many polyaromatic compounds are integral components of petroleum products (petrogenic PAHs) [11], so their presence may be associated with the fact of oil pollution in the region. Also, the presence of polyarenes is often associated with the combustion of various organic compounds as a result of human economic activity (pyrogenic PAHs) [11]. Due to these factors, the presence of PAHs of various origins can be assumed in the object under study.

In the Chernaya River estuary 14 PAHs were identified, 4 of them (naphthalene, 2-methylnaphthalene, fluorene, anthracene) - in the trace amounts (Fig. 2).

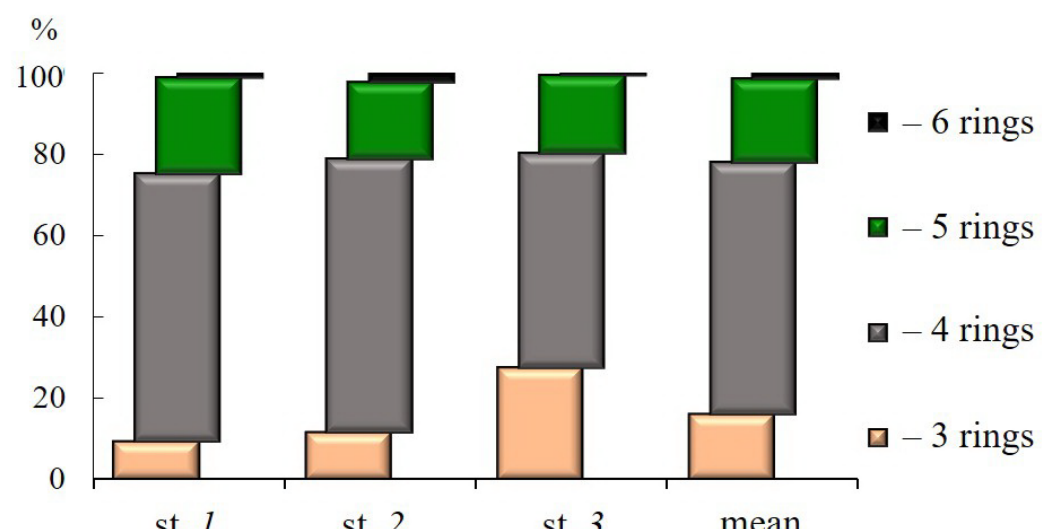

F i g. 2. The percentage of PAHs with different numbers of benzene groups, \% 
In the studied area, the largest proportion of PAHs fell on the compounds with four benzene rings (53-67\%). The total content of phenanthrene and chrysene accounted for $50 \% \sum \mathrm{PAH}$. These compounds are genetically related to higher terrestrial vegetation [11]. Their presence can be caused by both oil pollution and the washout and decomposition of organic matter from the coastal areas. It should be noted that with the movement from the river to the sea, the proportion of phenanthrene decreased and the proportion of chrysene increased. The total percentage of these substances was retained. Both compounds are widespread in nature, and are also the components of fuel and other petroleum products. The presence of phenanthrene is often associated with diesel and gasoline exhaust particles [14].

The portion of the most toxic PAHs, which are considered to be carcinogenic ones (5- and 6-ring), in total reached 25\% in the bay bottom sediments, in the river sediments it was slightly lower and amounted to $20 \%$. For comparison: in the bottom sediments of the Kazachya Bay, located southwestwards of the Sevastopol Bay, the proportion of such compounds in bottom sediments varied within 11-32\% [15]; in the Balaklava Bay, which is the base of a large small size fleet, according to our data it was 8-33\%. 6-ring PAHs were noted at all sampling stations. Their largest share was recorded in the area of st.1.

In order to identify the origin of PAHs, molecular indices, including the ratios of various components of pollution [14, 16, 17], were used. By the value of the obtained ratios, one can judge about the petrogenic or pyrolytic nature of the identified compounds (Table).

Molecular index values for PAHs of pyrolytic and petrogenic origin

\begin{tabular}{l|c|c|c|c}
\hline \multirow{2}{*}{ Molecular indices } & \multirow{2}{*}{$\begin{array}{c}\text { Min - max } \\
\text { (average value) }\end{array}$} & Pyrolytic & Petrogenic & \multirow{2}{*}{$\begin{array}{c}\text { Source of } \\
\text { data }\end{array}$} \\
\cline { 3 - 4 } & & $<10.0$ & $>15.0$ & {$[18]$} \\
\hline $\begin{array}{l}\text { Phenanthrene/anthracene } \\
\text { Fluoranthene/pyrene }\end{array}$ & $1.2-6.1(1.5)$ & $>1.0$ & $<1.0$ & {$[18]$} \\
$\begin{array}{l}\text { Fluoranthene/(fluoranthene } \\
+ \text { pyrene) }\end{array}$ & $0.5-0.9(0.6)$ & $>0.5$ & $<0.5$ & {$[18]$} \\
$\begin{array}{l}\text { Pyrene/benz(a)pyrene } \\
\begin{array}{l}\text { (Fluoranthene + pyrene)/ } \\
\text { (phenanthrene + chrysene) }\end{array}\end{array}$ & $4.6-12.2(7.8)$ & $<1.0$ & $>1.0$ & {$[17]$} \\
$\sum(2-4) / \sum(5-6)$ & 0.5 & $>1.0$ & $<1.0$ & {$[5]$} \\
\hline
\end{tabular}

The calculation (Table) demonstrated that the values of four indices out of six indicate the predominantly petrogenic origin of the detected PAHs. It can be concluded that the PAHs identified in the bottom sediments of the Chernaya River estuary zone are of mixed nature.

Benz(a)pyrene (B(a)P) is often used as a characteristic component for assessing the level of anthropogenic hydrocarbon pollution. Its toxic properties are well studied [19], tentatively safe exposure levels and maximum permissible concentrations (MPC) in various environmental components (HN 2.1.5.1315-03; 
HN 2.1.7.2041-06.2.1.7) have been determined for it. The toxicity of these substances is a relative unit of measurement for assessing the harmfulness of other polyaromatic compounds [8].

The $\mathrm{B}(\mathrm{a}) \mathrm{P}$ content in the bottom sediments of the area under study ranged from 0.08 to $6.19 \mathrm{ng} / \mathrm{g}$ at a standard concentration of $25 \mathrm{ng} / \mathrm{g}$ according to foreign standards Neue Niederlandische Liste. Altlasten Spektrum 3/95 (“Dutch lists”). Thus, the Chernaya River estuary and the surrounding areas can be considered favorable for this indicator. This assessment is not unambiguous due to the absence in the Russian Federation of documents regulating the $\mathrm{B}(\mathrm{a}) \mathrm{P}$ content in bottom sediments.

There are a number of methods that determine the standardization of this indicator. In particular, one of them proposes to take into account the granulometric composition of bottom sediments * as a factor which significantly affects the accumulation of pollutants. In accordance with this method, the B(a)P concentration in sands should not exceed $2 \mathrm{ng} / \mathrm{g}$, in silts $-5 \mathrm{ng} / \mathrm{g}$. The bottom areas with content above $30 \mathrm{ng} / \mathrm{g}$ are classified as heavily contaminated. In the area under study, the soils are predominantly represented by silt fractions (Fig. 3), i.e. $\mathrm{B}(\mathrm{a}) \mathrm{P}$ content in them should not exceed $5 \mathrm{ng} / \mathrm{g}$. As a result, st. 2 and 3 can be considered favorable for this indicator. At st. 1 , located in the bay water area, this figure is slightly exceeded (by 1.2 times).

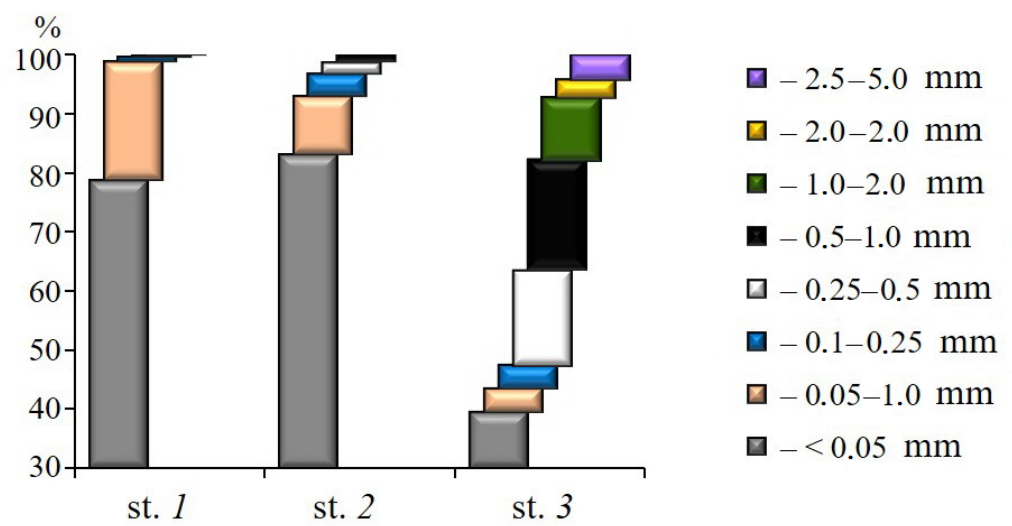

F i g. 3. Bottom sediments fractional composition in the water area under study

As is known [11, 13, 15], the ability of bottom sediments to accumulate various substances is largely related to their granulometric composition. In our case (Fig. 3) the maximum concentration of silty material (99\%) was observed in the water area of the Sevastopol Bay at a distance from the place of the Chernaya River inflow. The distribution of silty fractions is as follows: $20 \%$ falls on aleurite-pelitic fraction, $79 \%$ - on pelite-aleuritic one. As we approach the Chernaya River estuary, the ratio of the bottom sediment fractions changes. At the site of the direct river inflow into the bay water area, the accumulation of the sand fraction

* Trapido, M.A., 1985. [Distribution of Carcinogenic PAHs and Monitoring of the Aquatic Environment (by the Example of Water Bodies in the Baltic Region). Extended Abstract of Ph.D. Thesis]. Leningrad, 20 p. (in Russian). 
(7\%) is noted, as well as the maximum share of pelitic silts, which is apparently explained by the peculiarities of organic matter deposition on the marginal filter. In river bottom sediments, the contribution of the finely dispersed fraction is lower and does not exceed $40 \%$. In this case, the proportion of sand increases to $39 \%$, and a gravel fraction (18\%) appears. It is noted that as one moves from the bay to the river, the main parameters of sedimentation change: the depth decreases, the hydrodynamic activity increases, and sources of terrigenous material occur. It is this change that can explain the increase in the proportion of medium- and coarsegrained fractions in the bottom sediments.

Based on the granulometric composition data, an assessment of the dependence of $\Sigma \mathrm{PAH}$ and mass fractions of this pollutant class on the percentage of various components of the bottom sediments clastic material was carried out. An analysis of the dependence of PAHs content with different numbers of cycles on the proportion of bottom sediments size fractions (Fig. 4) revealed that the accumulation of PAHs individual fractions occurs similarly to the $2 \mathrm{PAHs}$ accumulation. For all studied groups, the greatest relationship was observed with a proportion of $0.1-0.05 \mathrm{~mm}$ size fraction. No positive dependence of PAH content on the proportion of other fractions of bottom sediments was noted. It was found that a decrease in the proportion of aleurite-pelitic fraction $(0.05-0.1 \mathrm{~mm})$ leads to a decrease in PAH concentrations in the bottom sediments. The largest concentration variations were noted for 4- and 5-ring PAHs, the content of which varies from 443 and $159 \mathrm{ng} / \mathrm{g}$ in the bay sediments to 6 and $2.3 \mathrm{ng} / \mathrm{g}$ in the river sediments, respectively (Fig. 4). The results obtained for the pelite-aleuritic fraction $(<0.05 \mathrm{~mm})$ are not so unambiguous.

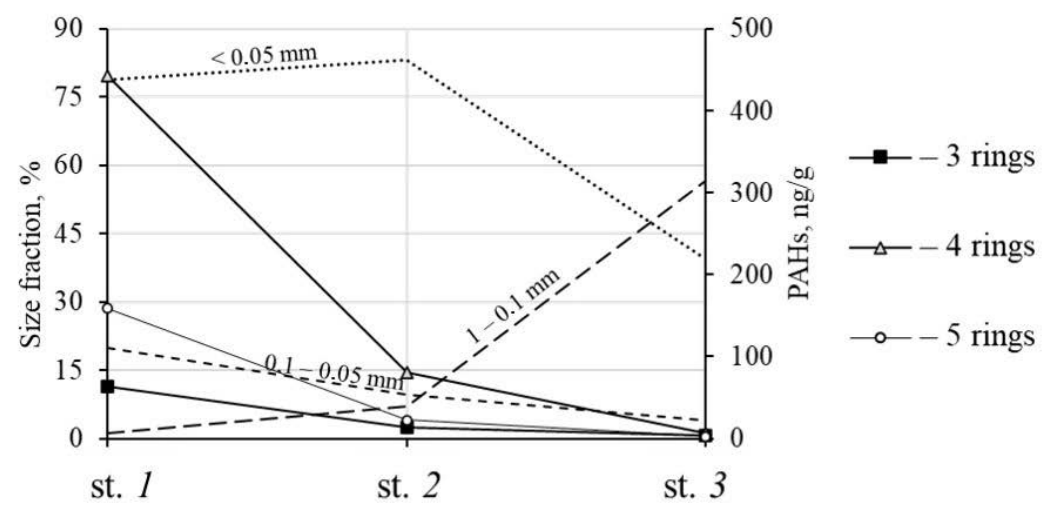

F i g. 4. Granulometric composition and content of the individual PAHs fractions in the bottom sediments surface layer in the water area under study

Thus, the known ability of bottom sediment finely dispersed fractions to accumulate pollutants of various types [11], including organic ones [20], was demonstrated. Note that this work did not reveal a bimodal dependence of PAHs accumulation on the granulometric composition of bottom sediments, which was 344

PHYSICAL OCEANOGRAPHY VOL. 28 ISS. 3 (2021) 
described in separate works. For example, according to [21], light molecules are associated with the sandy fraction, and heavy, 6-ring ones - with the silt fraction. In our case, the opinion of the author of the work [20] that the accumulation of organic matter in general (including PAHs) is mainly associated with the presence of silt in bottom sediments is confirmed.

As can be seen, as the river moved towards the sea, the total content of polyarenes increased, and their qualitative composition changed towards an increase in the proportion of more toxic compounds. As a rule, the river - sea geochemical barrier is a filter that prevents oil and pyrogenic hydrocarbons from penetrating into the open sea areas. This phenomenon is typical for the estuary areas of the Volga, Daugava, Danube and other rivers, i.e. it manifests itself regardless of climatic zones [11]. According to our data, such processes are not typical for the studied barrier. This is probably due to the fact that the pollution level according to the parameters under consideration is much higher in the bay than in the mixing zone and the river. In our case, most of the PAH input sources are located on the shores of the Sevastopol Bay and its water surface. The Chernaya River, flowing through relatively sparsely populated and ecologically safe suburban areas, contains in its waters (judging by the composition of bottom sediments) a small amount of pollutants. It is very likely that it is not a significant source of PAHs entering the water area of the Sevastopol Bay.

\section{Conclusions}

1. Total PAH content in the bottom sediments of the zone of the the Chernaya River confluence into the sea ranged from 12 to $670 \mathrm{ng} / \mathrm{g}$ of dry residue. The minimum PAH content values were recorded in the riverine part of the area under study, behind the so-called geochemical barrier. In the area of the Chernaya River confluence into the Sevastopol Bay, the PAH content was an order of magnitude higher $(121 \mathrm{ng} / \mathrm{g})$ than in the river bottom sediments. The largest $\sum \mathrm{PAH}$ was noted in the sea soils of the Sevastopol Bay, $1.5 \mathrm{~km}$ south-westward of the place where the Chernaya River confluence into the bay. The recorded values correspond to non-toxic background levels.

2. In the Chernaya River estuary zone 14 PAHs were identified, 4 of them (naphthalene, 2-methylnaphthalene, fluorene, anthracene) - in trace amounts. The largest part (50\%) accounted for the total content of phenanthrene and chrysene. The proportion of the most toxic compounds (5- and 6-ring), which are considered to be carcinogenic, in total reached $25 \%$ in the bay bottom sediments. In the river sediments, it was somewhat lower and amounted to $20 \%$.

3. The PAHs identified in the Chernaya River estuary zone bottom sediments are of mixed, predominantly petrogenic nature.

4. The $\mathrm{B}(\mathrm{a}) \mathrm{P}$ content in the bottom sediments of the area under study ranged from 0.08 to $6.19 \mathrm{ng} / \mathrm{g}$. The obtained data were compared with the standards, the so-called "Dutch lists", as well as with conditional standards, in which it is proposed to take into account the granulometric composition of bottom sediments as a factor that significantly affects the accumulation of pollutants. In accordance with foreign standards, the Chernaya River estuary and the surrounding areas can be considered favorable for this indicator. According to the conventional standards, in the bay area adjacent to the estuary, this figure was exceeded by 1.2 times. 
5. Analysis of the relationship between the granulometric composition of bottom sediments and the PAHs accumulation in them showed that the maximum accumulation of this class of substances occurs in the silt fraction, to a greater extent in the fractional group of $0.05-0.1 \mathrm{~mm}$. Thus, in the conditions of the river sea contact zone, the accumulation of PAHs as a whole and their individual fractions is mainly determined by the presence of silt in the bottom sediments.

\section{REFERENCES}

1. Lisitsyn, A.P., 1995. The Marginal Filter of the Ocean. Oceanology, 34(5), pp. 671-682.

2. Moiseenko, O.G., Khoruzhiy, D.S. and Medvedev, E.V., 2014. Carbonate System in the Chernaya River Waters and in the Zone of the Chernaya River - Sevastopol Bay Biogeochemical Barrier (the Black Sea). Morskoy Gidrofizicheskiy Zhurnal, (6), pp. 47-60 (in Russian).

3. Koshovskii, T.S., Tkachenko, O.V., Tkachenko, A.N., Tsibart, A.S. and Lychagin, M.Yu., 2017. Polycyclic Aromatic Hydrocarbons in the Aquatic Landscapes of the Don River Delta in Winter. Izvestiya Vuzov. Severo-Kavkazskii Region. Natural Science, (2), pp. 118-127. doi:10.23683/0321-3005-2017-2-118-127 (in Russian).

4. Khalikov, I.S., 2018. Identification of Sources of Environmental Pollution by Polycyclic Aromatic Hydrocarbons on the Basis of Their Molar Ratios. Russian Journal of General Chemistry, 88(13), pp. 2871-2878. https://doi.org/10.1134/S1070363218130078

5. Rovinskiy, F.Y., Teplitskaya, T.A. and Alexeyeva, T.A., 1988. Background Monitoring of Polycyclic Aromatic Hydrocarbons. Leningrad: Gidrometeoizdat, 224 p. (in Russian).

6. Neff, J.M., 2002. Bioaccumulation in Marine Organisms: Effects of Contaminants from Oil Well Produced Water. Amsterdam: Elsevier, 468 p. https://doi.org/10.1016/B978-0-08-043716-3.X5000-3

7. Ilnitsky, A.P., Korolev, A.A. and Khudoley, V.V., 1993. [Carcinogenic Substances in the Aquatic Environment]. Moscow: Nauka, 222 p. (in Russian).

8. Opekunov, A.Yu., Mitrofanova, E.S., Sanni, S., Kommedal, R., Opekunova, M.G. and Bagi, A., 2015. Polycyclic Aromatic Hydrocarbons in the Bottom Sediments of Rivers and Canals of Saint Petersburg. Vestnik Sankt-Peterburgskogo Universiteta Seriya 7 Geologiya Geografiya, (4), pp. 98-109 (in Russian).

9. Burgess, R.M., Terletskaya, A.V., Milyukin, M.V., Povolotskii, M., Demchenko, V.Y. Bogoslavskaya, T.A., Topkin, Yu.V., Vorobyova, T.V., Petrov, A.N., Lyashenko, A. and Ho, K.T., 2009. Concentration and Distribution of Hydrophobic Organic Contaminants and Metals in the Estuaries of Ukraine. Marine Pollution Bulletin, 58(8), pp. 1103-1115. https://doi.org/10.1016/j.marpolbul.2009.04.013

10. Savinov, V., Larsen, L-H., Green, N., Korneev, O., Rybalko, A. and Kochetkov, A., 2011. Monitoring of Hazardous Substances in the White Sea and Pechora Sea: Harmonisation with OSPAR's Coordinated Environmental Monitoring Programme (CEMP). Tromsø, 71 p.

11. Nemirovskaya, I.A., 2013. Oil in the Ocean (Pollution and Natural Flows). Moscow: Nauchnyy mir, 432 p. (in Russian).

12. Larin, A.A., Pavlenko, L.F., Skrypnik, G.V. and Korpakova, I.G., 2011. Oil Pollution of the Black Sea Coastal Environment. Morskoj Ehkologicheskij Zhurnal = Marine Ekological Journal, (2), pp. 49-55 (in Russian).

13. Mironov, O.G., Kirjukhina, L.N. and Alyomov, S.V., 2003. Sanitary-Biological Aspects of the Sevastopol Bays Ecology in XX Century. Sevastopol: ECOSI-Gidrofizika, 185 p. (in Russian).

14. Wang, D.-G., Yang, M., Jia, H.-L., Zhou, L. and Li, Yi-F., 2009. Polycyclic Aromatic Hydrocarbons in Urban Street Dust and Surface Soil: Comparisons of Concentration, Profile, and Source. Archives of Environmental Contamination and Toxicology, 56(2), pp. 173-180. doi:10.1007/s00244-008-9182-X

15. Soloveva, O.V., Tikhonova, E.A., Klimenko, T.L., Skrupnik, G.V. and Votinova, T.V., 2019. Organic Compounds in Bottom Sediments under Conditions of Coastal Urbanization (a Case 
Study of Kazach’ya Bay of the Black Sea). Oceanology, 59(2), pp. 214-222. https://doi.org/10.1134/S0001437019020176

16. Pavlenko, L.F., Skrupnik, G.V., Klenkin, A.A. and Korpakova, I.G., 2008. Pollution of the Azov Sea with Polyaromatic Hydrocarbons. Problems of Fisheries, 9(4), pp. 861-869 (in Russian).

17. Soclo, H.H., Garrigues, Ph. and Ewald, M., 2000. Origin of Polycyclic Aromatic Hydrocarbons (PAHs) in Coastal Marine Sediments: Case Studies in Cotonou (Benin) and Aquitaine (France) Areas. Marine Pollution Bulletin, 40(5), pp. 387-396. https://doi.org/10.1016/S0025-326X(99)00200-3

18. Baumard, P., Budzinski, H., Garrigues, P., Dizer, H. and Hansen, P.D., 1999. Polycyclic Aromatic Hydrocarbons in Recent Sediments and Mussels (Mytilus edulis) from the Western Baltic Sea: Occurrence, Bioavailability and Seasonal Variations. Marine Environmental Research, 47 (1), pp. 17-47. https://doi.org/10.1016/S0141-1136(98)00105-6

19. Israel, Yu.A. and Tsyban, A.V., 1989. Anthropogenic Ecology of the Ocean. Leningrad: Gidrometeoizdat, 528 p. (in Russian).

20. Mitropolsky, A.Y., Bezborodov, A.A. and Ovsyany, E.I., 1982. [Geochemistry of the Black Sea]. Kiev: Naukova dumka, 144 p. (in Russian).

21. Krein, A. and Schorer, M., 2000. Road Runoff Pollution by Polycyclic Aromatic Hydrocarbons and Its Contribution to River Sediments. Water Research, 34(16), pp. 41104115. https://doi.org/10.1016/S0043-1354(00)00156-1

About the authors:

Olga V. Soloveva, Senior Research Associate, Department of Marine Sanitary Hydrobiology, FSBSI FRC “A.O. Kovalevsky Institute of Biology of the Southern Seas of RAS” (2 Nakhimova Pr., Sevastopol, 299011, Russian Federation), Ph. D. (Biology), ORCID ID: 0000-0002-1283-4593, Scopus Author ID: 57208499211, ResearcherID: X-4793-2019, kozl_ya_oly@mail.ru

Elena A. Tikhonova, Senior Research Associate, Department of Marine Sanitary Hydrobiology, FSBSI FRC “A.O. Kovalevsky Institute of Biology of the Southern Seas of RAS" (2 Nakhimova Pr., Sevastopol, 299011, Russian Federation), Ph. D. (Biology), ORCID ID: 00000002-9137-087X, Scopus Author ID: 57208495804, ResearcherID: X-8524-2019, tihonoval@mail.ru

Oleg A. Mironov, Senior Research Associate, Department of Marine Sanitary Hydrobiology, FSBSI FRC “A.O. Kovalevsky Institute of Biology of the Southern Seas of RAS” (2 Nakhimova Pr., Sevastopol, 299011, Russian Federation), Ph. D. (Biology), Scopus Author ID: 56227568700, ResearcherID: ABH-9273-2020, mironov87@gmail.com

Timofey O. Barabashin, Deputy Head, Azov-Black Sea Branch of "VNIRO” (“AzNIIRKH”) (21v Beregovaya str., Rostov-on-Don, 344002, Russian Federation), Ph. D. (Biology), ORCID ID: 0000-0002-4103-6224, timbar@bk.ru

Contribution of the co-authors:

Olga V. Soloveva - setting goals, describing the qualitative and quantitative composition of PAHs, assessing potential sources of PAHs entering the bottom sediments of the river - sea mixing zone, formulating conclusions, writing a paper

Elena A. Tikhonova - preparation of bottom sediment samples for chemical analysis, assessment of the relationship between the granulometric composition of bottom sediments and the content of PAHs in them, formulation of conclusions

Oleg A. Mironov - taking samples of bottom sediments, preparation of the paper in accordance with the journal requirements

Timofey O. Barabashin - selection and analysis of literary sources for the assigned research objectives, preparation of a literature review, coordination of the process of determining the concentration of PAHs in the bottom sediments

All the authors have read and approved the final manuscript.

The authors declare that they have no conflict of interest. 